\title{
Analysis of the availability of the resources necessary for urgent and emergency healthcare in São Paulo between 2009-2013
}

\author{
Silvana Hebe Coimbra ${ }^{1 *}$, Eliete Dominguez Lopez Camanho ${ }^{2}$, Lindolfo Carlos Heringer ${ }^{1}$, Ricardo Vieira Botelho ${ }^{1}$, \\ Cidia Vasconcellos ${ }^{1}$
}

${ }^{1}$ Graduate Program, Instituto de Assistência Médica ao Servidor Público Estadual, São Paulo, SP, Brazil ${ }^{2}$ Fundação para o Desenvolvimento Científico e Tecnológico da Odontologia, São Paulo, SP, Brazil

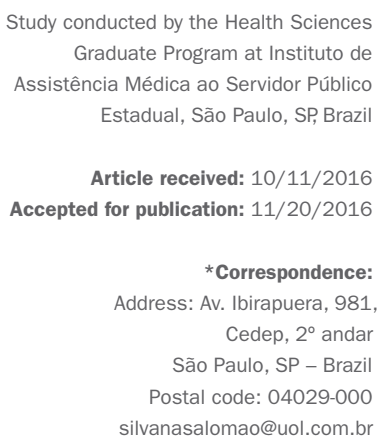

\section{SUMMARY}

Introduction: The Regulatory Complex is the structure that operationalizes actions for making resources available to meet the needs of urgent and emergency care in the municipality of São Paulo. In the case of urgent care, needs are immediate and associated with high morbidity and mortality.

Objective: To identify the most frequently requested resources, the resolution capacity and the mortality rate associated with the unavailability of a certain resource.

Method: Our study was based on data from medical bulletins issued by the Urgent and Emergency Regulation Center (CRUE) in the city of São Paulo from 2009 to 2013. Results: 91,823 requests were made over the five years of the study (2009 to 2013). Neurosurgery requests were the most frequent in all years $(4,828,5,159,4,251,5,008$ and 4,394, respectively), followed by computed tomography (CT) scans, adult intensive care unit (ICU) beds, cardiac catheterization, and pediatric ICU beds. On average, requests for neurosurgery, adult ICU, pediatric ICU, CT scans, catheterization and vascular surgery were answered in $70 \%, 27 \%, 39 \%, 97 \%, 87 \%$ and $77 \%$ of cases. The total number of deaths relating to requests for neurosurgery, CT scans, adult ICU, pediatric ICU, catheterization and vascular surgeon assessment were 182, 9, $1,536,1,536,135,49$ and 24 cases, respectively.

Conclusion: There is a lack of resources to meet urgent and emergency needs in the city of São Paulo.

Keywords: health systems, health care coordination and monitoring, emergency medical services, health care (public health), unified health system, neurosurgery.

\section{INTRODUCTION}

The metropolitan areas of large urban centers require a large amount of resources for the treatment of the population's health. ${ }^{1}$ In urgent and emergency cases, these needs are immediate due a high morbidity and mortality. ${ }^{2-4}$

The Regulatory Complex is the structure that operationalizes actions for making resources available to a particular population, providing them according to preestablished criteria and protocols to be followed. It was created to ensure access to the resources by the many existing demands. ${ }^{5}$

In this sense, "regulation" means the intermediation of actions to improve access in a planned manner, in order to reduce shortfalls in the pursuit of efficiency, quality and effectiveness. ${ }^{6}$

The Municipal Regulatory Complex of São Paulo is administrated by the Municipal Health Department (SMS) and regulates the population's access to health resources in the city of São Paulo.?

\section{Objective}

To identify the need for the most frequently requested resources, the resolution capacity and mortality rate associated with the unavailability of the resource and trends throughout the years of our study.

\section{Method}

Our study was based on data from medical bulletins issued by the Urgent and Emergency Regulation Center (CRUE) in the city of São Paulo from 2009 to 2013.

The survey was conducted with consent of the SMS of São Paulo and approval by the Research Ethics Committee (No. 519,944, February 2014). There are no conflicts of interest among any of the authors in relation to this manuscript that need to be declared. 


\section{Variables included}

\section{The need for urgent and emergency resources}

The six most frequently requested resources for emergency care in the city of São Paulo (absolute figures) in the five years of the study were tabulated. Absolute figures and proportions for the other requested resources were described, as well as the trends per year.

\section{Resolution of requests}

Resolution capacity was defined by the number of cases resolved and their percentage in relation to the number of requests. These were described per year of the study.

\section{Deaths per type of request}

The number of deaths related to certain request and the percentage in relation to the number of requests and their trends per year were described. Deaths were noted as one of the types of outcomes (resolution) of the request.

\section{Use of the Zero Vacancy ("Vaga Zero") tool}

A separate analysis of the Zero Vacancy tool used for care requiring neurosurgical evaluation. The Zero Vacancy tool is based on the Federal Board of Medicine (CFM) no. $1671 / 03$, published in the Federal Official Gazette in July 2003, in accordance with MS (Ministry of Health) Ordinance no. 2048/2002. It states that, even in situations where there are no vacant beds for patient hospitalization, the hospital unit must still guarantee care. From the point of view of urgent and emergency care, there is a tool for access of patients at imminent death risk in the case of inexistent local resources or the refusal of the evaluation from the referencial service. Therefore, the amount of care provided with the Zero Vacancy tool was recorded as an increasing percentage over the years of study.

Trends were evaluated between the years of the study in the resource requests, resolution of resources and fatality trends (deaths).

\section{Statistical analysis}

EPI INFO 6.0 software and Excel spreadsheets were used.

Data treatment and analysis was performed descriptively, with numbers and percentages.

\section{RESULTS}

\section{Need for resources}

\section{Largest resource requests}

A total of 91,258 requests were made over the five years of the study (2009 to 2013).

The six largest requests were described per year of the study (Figure 1).
Neurosurgery requests were the most frequent in all years. Between 2009 and 2013, 4,828, 5,159, 4,251, 5,008 and 4,394 requests were made, respectively.

CT scan requests were the second most frequent. The type of CT scan most frequently requested was skull. The number of requests per year was 2,946, 2,612, 2,287, 1,641 and 3,106, respectively.

Adult intensive care unit (ICU) beds were the third most frequent request, totaling 2,809, 3,164, 1,869, 1,691 and 1,496 , respectively, over the years studied.

The request for cardiac catheterization appeared in the year 2010 for the first time on record, as the fourth most frequent request. Between 2009 and 2013, 811, 1,041, 1,803 and 1,146 examinations were requested, respectively.

Pediatric ICU admission was the fifth cause of requests. These occurred at a frequency of 897, 1,002, 822, 818 and 686 , respectively. Other less frequent requests were described in Figure 1.

\section{Resolutions of requests}

The resolution of the requested resources were described in absolute figures and as a proportion of the resolutions in relation to the requested resource, over the five years of the study (Figure 1).

Requests for neurosurgery, adult ICU, pediatric ICU, CT scans, catheterization and vascular surgery were answered (resolved) in 70\%, 27\%, 39\%, 97\%, 87\% and $77 \%$ of cases, respectively.

\section{Deaths by type of unanswered request (Table 1)}

Over the five years of the study, the total number of deaths relating to requests for neurosurgery, CT scans, adult ICU, pediatric ICU, catheterization and vascular surgeon assessment were 182, 9, 1,536, 135, 49 and 24 cases, respectively.

\section{Use of the Zero Vacancy tool}

The Zero Vacancy tool was used 298, 535, 512, 690 and 814 times in the years 2009 to 2013, respectively (Figure 2).

TABLE 1 Number of deaths/year (per type of request).

\begin{tabular}{lllllll} 
Request & \multicolumn{7}{l}{ Number of deaths } \\
\hline & $\mathbf{2 0 0 9}$ & $\mathbf{2 0 1 0}$ & $\mathbf{2 0 1 1}$ & $\mathbf{2 0 1 2}$ & $\mathbf{2 0 1 3}$ & Total \\
\hline Neurosurgery & 25 & 27 & 28 & 58 & 44 & 182 \\
\hline Tomography & 1 & 3 & 1 & 3 & 1 & 9 \\
\hline Adult ICU & 301 & 472 & 303 & 243 & 217 & 1,536 \\
\hline Pediatric ICU & 15 & 28 & 30 & 40 & 22 & 135 \\
\hline Catheterization & - & 5 & 17 & 15 & 12 & 49 \\
\hline Vascular surgery & - & 3 & 4 & 7 & 10 & 24 \\
\hline
\end{tabular}




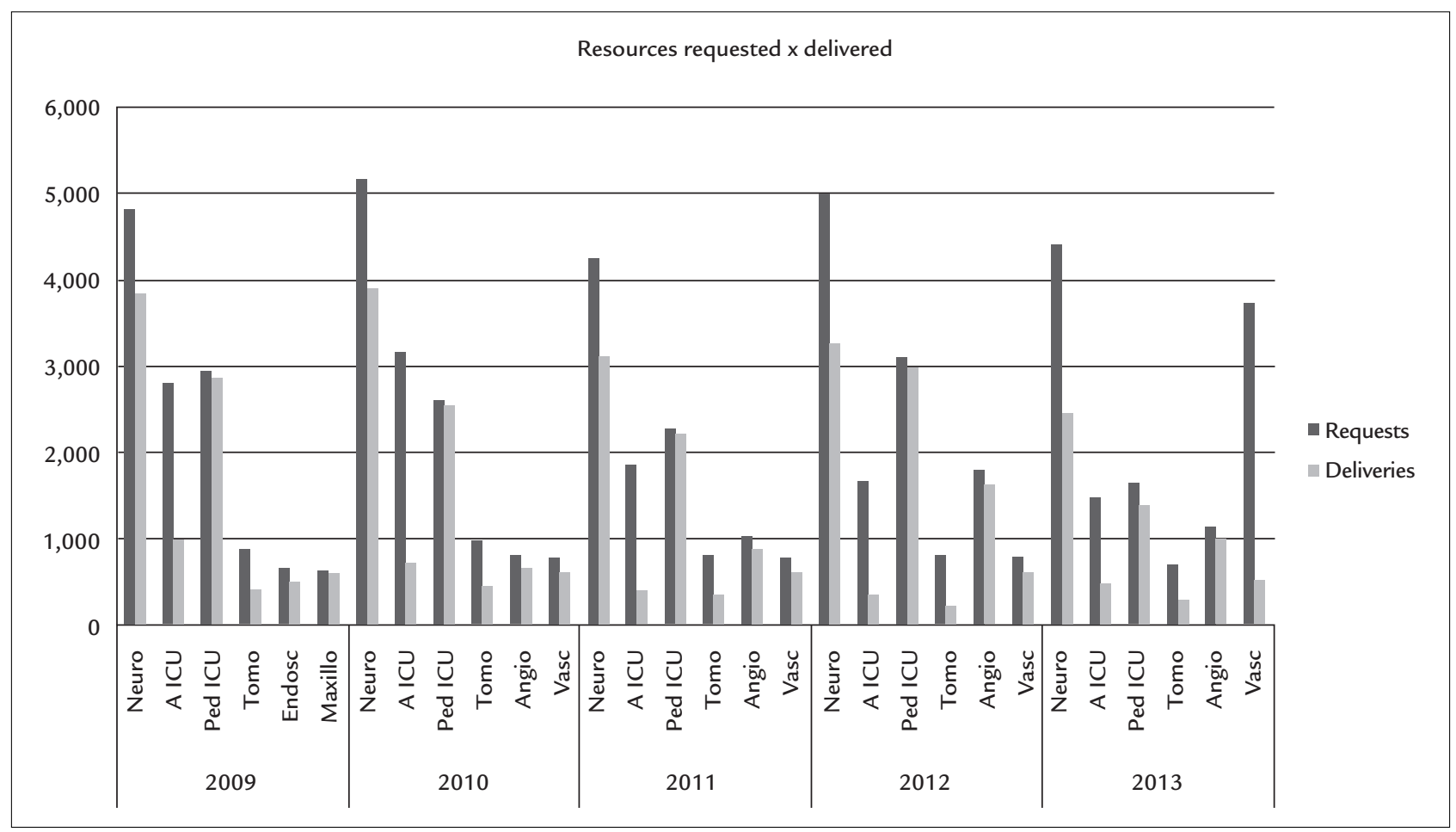

FIGURE 1 Trends in resources requested and delivered from 2009 to 2013.

Neuro: neurosurgery; A ICU: adult ICU; Tomo: CT scan; Ped ICU: pediatric ICU; Endosc: endoscopy; Angio: angiography; Vasc: vascular surgery; Maxillo: oral and maxillofacial surgery.

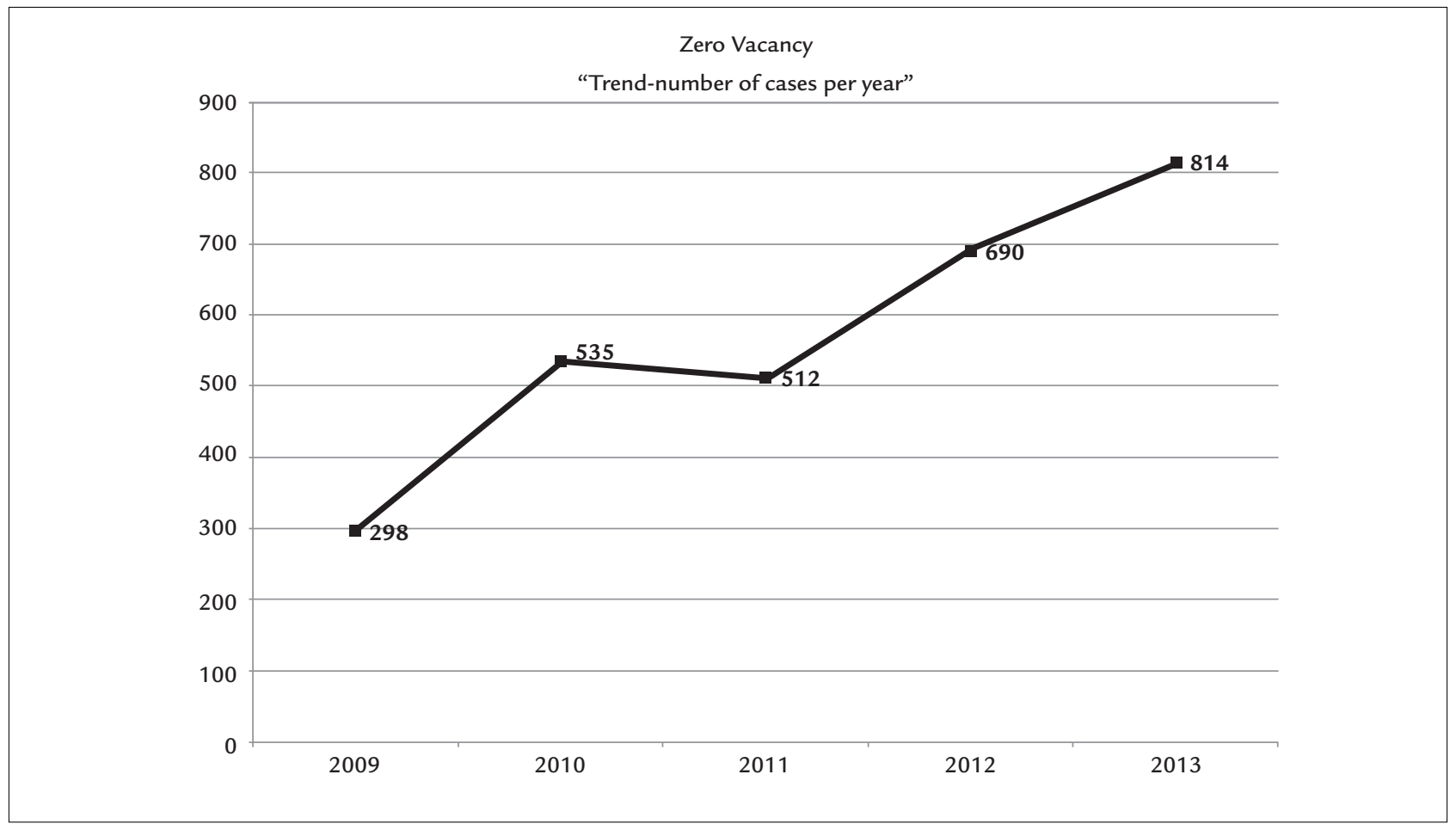

FIGURE 2 Trends in neurosurgery request resolution, such as Zero Vacancy, per year. 
Trends

\section{Trends in resource requests}

The requests for neurosurgery remained high throughout the period but stable, with no upward or downward trends. Catheterization requests also remained stable (Figure 1).

Tomography and adult ICU beds had a decrease in requests. In 2009, 2,946 tomography scans were requested, and 1,641 in the year 2013. In 2009, 2,809 beds were requested at the adult ICU, while in 2013 this number was 1,496 . Vascular surgery had an increase of 4.7 times in the number of requests over the five years studied (Figure 1).

\section{Trends in resource resolutions}

There was a trend towards a decrease in resolutions for neurosurgery. The percentage of resolutions in the other requests was stable. The resolution percentage related to the need for pediatric and adult ICU resources was very low, at 39 and $27 \%$, respectively.

\section{Trends in mortality (Table 1)}

The average mortality rate associated with the need for adult ICU is 8.4 times that of neurosurgery. The trend of fatality rates in the adult ICU, although high, decreased between 2010 to 2013, falling from 472 deaths to 217 . The mortality of neurosurgery and vascular surgery shows an upward trend over the period.

\section{Trends in the use of the Zero Vacancy tool}

The Zero Vacancy tool was used more times in 2013 than in 2009, thus showing an upward trend of use (Figure 2). This trend increased inversely with the availability of the "neurosurgery" resource at the CRUE of São Paulo.

\section{Discussion}

In Brazil, the annual investment in the health area is $4.1 \%$ of the gross domestic product (GDP), which is considered insufficient in providing care and access for all. ${ }^{1}$

At the time of the study, the city of São Paulo, Brazil's most populous city, had a population of 10,886,518 inhabitants, and was $9^{\text {th }}$ in total area. ${ }^{2}$

The implementation of the Regulatory Complex was undertaken to prioritize the flow of care and reconcile the needs with the capacity of each health unit. ${ }^{6}$ The CRUE-SP regulates the inter-hospital flow of emergency care in the city of São Paulo for diagnosis, clinical evaluation, surgical or ICU needs linked to the public healthcare system (SUS). It is estimated that the absence of the CRUE's intervention in the regulation would lead to greater mortality among patients.
In order to evaluate the capacity to meet the needs of urgencies and emergencies in the years 2009 to 2013, we investigated the most frequent requests. Neurosurgery evaluation (NCR), vascular surgery evaluation, CT scans, adult ICU, catheterization and pediatric ICU were the greatest care needs.

Tomography requests were met in 98 to $99 \%$ of cases. The lack of local imaging resources implies the need for referral to the Regulation Center in order to remedy these local shortcomings, as recommended by the Organization for Economic Cooperation and Development (OECD). ${ }^{8}$

Catheterization requests were incorporated into the CRUE-SP in 2010 and met in 80 to $88 \%$ of cases.

Adult ICU requests were only met in 20.8 to $36 \%$ of requests, due to lack of resources.

For the pediatric ICU, there was an average request resolution of $40 \%$ of requests.

The resource most often requested among all was the neurosurgical service. There is a lack of neurosurgical care in the network. ${ }^{9}$ Head trauma and stroke are a frequent cause of demand for imaging examinations for diagnosis, intensive care, neurosurgical evaluation and treatment. These are serious conditions, with a high potential for morbidity and mortality. ${ }^{10}$

A discussion on the trends in the provision of resources and their consequences is required. The mortality of the most requested resource, that is, neurosurgery, increased in 2012 and 2013. Resolution of the neurosurgery resource has been gradually decreasing and the use of the Zero Vacancy tool has been increasing, probably to resolve the demand for the latter. We do not have information on the prognosis of patients cared for under the Zero Vacancy tool.

Mortality related to lack of cardiac catheterization has decreased, probably due to greater supply of the resource through centers that carry out the procedure contracted by the SMS.

Mortality due to lack of vascular surgery continued increasing in the years investigated.

Less frequent needs such as oral and maxillofacial surgery, endoscopy etc., which only appeared among the most frequent requests in the first year, also deserve the attention of specific studies.

The data shows the lack of resources to meet urgent and emergency needs in the city of São Paulo. The trends showed no improvement in the number of resource requests in the years studied. There is high mortality associated with the request for adult and pediatric ICU beds.

There was an increased use of the Zero Vacancy resource in the demand for neurosurgery, as opposed to a progressive decrease in the resolution of neurosurgery services. 
Knowledge of the real needs of the population has not been established since SMS Ordinance 245/2007. ${ }^{11}$ The study and mapping of these needs has the potential to reveal the lack of resources and the risks to the population, in order to guide the allocation of the necessary resources.

\section{Conclusion}

The most requested resource was neurosurgery, followed by CT scans, adult ICU beds, cardiac catheterization and pediatric ICU beds. There was a downward trend in neurosurgery resolutions associated with increased use of the Zero Vacancy resource. Resolution of pediatric and adult ICU needs was low. There was significant mortality associated with the lack of resources.

\section{Conflict of interest}

The authors declare no conflict of interest.

\section{Resumo}

Análise da disponibilidade de recursos necessários para o atendimento de urgência e emergência em saúde no município de São Paulo entre 2009-2013

Introdução: O Complexo Regulador é a estrutura que operacionaliza as ações de acesso aos recursos para atendimento de urgência e emergência médicas no município de São Paulo. Nas urgências, as necessidades são imediatas e associadas a elevada morbidade e mortalidade.

Objetivo: Identificar os recursos mais frequentemente solicitados, a capacidade de resolução e o índice de mortalidade associado à falta do recurso.

Método: Este trabalho foi baseado nos dados dos boletins médicos da Central de Regulação de Urgência e Emergência (CRUE) do Município de São Paulo, nos anos de 2009 a 2013.

Resultados: Foram feitas 91.823 solicitações nos cinco anos do estudo (2009 a 2013). As solicitações de neurocirurgia foram as mais frequentes em todos os anos (4.828, $5.159,4.251,5.008$ e 4.394 , respectivamente), seguidas pela tomografia, vaga de UTI adulto, cateterismo cardíaco e UTI pediátrica. Em média, os pedidos de neurocirurgia, UTI adulto, UTI infantil, tomografia, cateterismo e cirurgia vascular foram atendidos em $70 \%, 27 \%, 39 \%, 97 \%, 87 \%$ e $77 \%$ dos casos. O número total de óbitos associados à falta de recurso para neurocirurgia, tomografia, UTI adulto, UTI infantil, cateterismo e avaliação de cirurgião vascular foram de 182, 9, 1.536, 135, 49 e 24 casos, respectivamente.

Conclusão: Há elevada falta de recursos para suprimento das necessidades de urgência e emergência no município de São Paulo.

Palavras-chave: sistemas de saúde, regulação e fiscalização em saúde, serviços médicos de emergência, serviços de saúde, sistema único de saúde, neurocirurgia.

\section{References}

1. Paulus Júnior A, Cordoni Júnior L. Políticas públicas de saúde no Brasil. Espaço Saúde. 2006; 8(1):13-9.

2. Barbosa DV. Regulação médica do fluxo das urgências: análise do complexo regulador de Goiânia [dissertation]. Anápolis (GO): UNIEVANGÉLICA Centro Universitário de Anápolis; 2012.

3. Dallari SG, Pittelli SM, Pirotta WR, Oliveira ML. Atendimento médico e urgência na grande São Paulo. Saúde Soc. 2001; 10(2):75-99.

4. Martins EFF. Avaliar o cumprimento do protocolo nacional de traumatismo crânio-encefálico no serviço de urgência do hospital de Santo António [dissertation]. Porto (Portugal): Instituto de Ciências Biomédicas de Abel Salazar, Universidade do Porto; 2011. Available from: https://repositorioaberto.up.pt/bitstream/10216/52783/2/Tese $\% 20$ Mestrado\%20\%20 Eduarda\%20Martins\%20texto\%20corrido.pdf.

5. Brasil. Ministério da Saúde. Portaria no 373, de 27 de fevereiro de 2002. Available from: http://bvsms.saude.gov.br/bvs/sadelegis/gm/2002/ prt0373_27_02_2002.html

6. Paim J, Travassos C, Almeida C, Bahia L, Macinko J. The Brazilian health system: history, advances, and challenges. Lancet. 2011;377(9779):1778-97.

7. Brasil. Ministério da Saúde. Portaria n ${ }^{\circ} 1.559$, de 1 de agosto de 2008. Available from: http://bvsms.saude.gov.br/bvs/saudelegis/gm/2008/ prt1559_01_08_2008.html

8. Santos DL, Leite HJ, Rasella D, Silva SA. Capacidade de produção e grau de utilização de tomógrafo computadorizado no Sistema Único de Saúde. Cad Saúde Pública. 2014; 30(6):1293-304.

9. Brasil. Ministério da Saúde. Secretaria de Vigilância à Saúde. Instituto Brasileiro de Geografia e Estatística - IBGE. Sistema de informações de mortalidade 2013. Available from: http://ces.ibge.gov.br/base-de-dados/metadados/ ministerio-da-saude/sistema-de-informacoes-de-mortalidade-sim.

10. Martins SCO, Seewald RA, Brondani R, Alves CV. Doença cerebrovascular. In: Chaves MF, Finkelsztejn A, Stefani MA, editors. Rotinas em neurologia e neurocirurgia. Porto Alegre: Artmed; 2008. p. 93-6.

11. São Paulo. Secretaria Municipal de Saúde de São Paulo. Portaria no 245/2007 - CIRS/SMS.G. Normatiza o fluxo de atenção às urgências e emergências no âmbito do Município de São Paulo. Diário Oficial do Município de 31 de mar de 2007, folha 24. 